\title{
Technological Landscape and Collaborations in Hybrid Vehicles Industry*
}

\author{
Marisela Rodríguez, Francisco Paredes
}

\author{
Marisela Rodríguez — Professor. E-mail: marisrod@itesm.mx \\ Francisco Paredes — Research Fellow. E-mail: franciscoparedesleon@gmail.com \\ Centro de Innovación en Diseño y Tecnología, Tecnológico de Monterrey) \\ Address: Avenida Eugenio Garza Sada 2501 Sur, Colonia Tecnológico, Monterrey, Nuevo León, \\ 64849, México
}

Keywords

patent analysis; hybrid vehicles; collaborative research; hybrid electric vehicles (HEV); green car technology

DOI: 10.17323/1995-459X.2015.2.6.21

Citation: Rodríguez M., Paredes F. (2015) Technological Landscape and Collaborations in Hybrid Vehicles Industry. Foresight-Russia, vol. 9, no 2, pp. 6-21. DOI: 10.17323/1995459x.2015.2.6.21

The production of hybrid vehicles has experienced intense growth in recent years. Carmakers invest significant resources into the development of advanced hybrid vehicles. The global prospects of this process can be estimated by systematically analyzing patents outlined in international patent databases.

The paper assesses the state-of-art and the future of the industry. Evidence from leaders in the development of hybrid vehicles demonstrates the productivity of the methodology for analyzing patent data developed by the authors.

$\mathrm{T}$ he use of environmentally friendly energy sources represents a need that society must address. The fact that fossil fuels represent approximately $80 \%$ of overall fuel usage [Sawin, 2012] shows the extent to which society today depends on fossil fuels. Gas emissions have increased the effects of global warming, affecting the Earth and sea levels. Over the last 30 years, several hurricanes have occurred due to climate change, and the habitats of at least 279 species in the Arctic and Antarctic are threatened [Márquez, 2007].

The use of fossil fuels affects not only the air quality but also the quality of water, soil, flora, and fauna, causing environmental and social disasters [Burns, Levings, 1993]. Birds, fish, corals, and other marine wildlife are harmed by water pollution, of ten caused by oil spills. Fossil fuels produce chemicals and toxic compounds which alter the growth of plants and ultimately affect human health [Marinescu et al., 2011].

These environmental problems require radical changes in the use of energy within the automotive sector. There have been extensive efforts to develop new technologies for hybrid vehicles in recent years to address these issues.

The US implemented important laws and policies focusing on zero emissions in the early 1990s (e.g. the Amendment to the Clean Air Act in 1990, the Energy Policy Act in 1992, and other regulations issued by the California Air Resources Board). Other initiatives for the development of hybrid vehicles were introduced in the early 21st century [US Department of Energy, 2005].

It is expected that the rise of emerging economies will lead to more demand for hybrid vehicles. The new opportunities for economic growth created in these

* We thank all of those who directly and indirectly provided academic support for the development of this research. In particular, we would like to thank the Advanced Manufacturing Research Group of Tecnológico de Monterrey. Additionally, we would like to thank Alejandro Palacios, Daniel Esquivel and Ana Marcela Hernández (Research Assistants) for their we would like to thank Ale
valuable time and support. 
countries do, however, adversely affect the prospects for sustainable development. In this sense, hybrid electric vehicles (HEV) could play an important role, particularly in China, India, and in Western countries [Porter et al., 2015].

The leaders in the automobile industry - namely, Toyota ${ }^{1}$, Nissan, Honda and General Motors - have been creating new technologies in order to use renewable energy sources in their vehicles. According to Dijk and Yarime [Dijk, Yarime, 2010], the market for Hybrid Electric Vehicles (HEVs) became sustainable after 1995. Toyota introduced the Prius to the Japanese market in 1997, while Honda presented the Insight in California the following year. By 2002, the cumulaive HEV sales exceeded 100,000 vehicles and reached 1.5 million by 2008 .

Since then, the major automotive companies have been increasingly involved in the development of ecological vehicles. More than 30 companies have emerged or expanded their efforts in the United States to provide pioneering solutions for vehicle pollution: Baker, Detroit Electric, GE, Studebaker, and Woods to name just a few [Kraft, 2012]. More than six million Toyota hybrid vehicles had been sold worldwide as of the end of 2013 [Custommedia, 2014a]. The Nissan Leaf, the first vehicle with zero emissions, achieved sales of 100,000 units and a presence in 35 countries between December 2012 and January 2014 [Custommedia, 2014b].

During the last few decades, automotive companies have increased collaboration to develop new technologies. Government initiatives play a key role. Japan planned to invest 21 billion yen (US\$ 264 million) from 2009 to 2015. The 'Next Generation Vehicle Strategy' will support the development of new batteries used in electricity based vehicles. The US announced plans to invest US $\$ 136$ billion in green energies (including green cars) from 2009 to 2018 through the Green New Deal initiative. The EU has invested 5 billion Euros (US\$ 6.6 billion) to support the European Green Car Initiative announced in November 2008 [Kwon, Jeong, 2013].

Technological advances in the field of hybrid vehicles are clearly reflected in patents. Because of this, scientometric patent analysis is now often used to identify technological advances in the field.

This study complements patent analysis with the Systems Engineering approach to study hybrid vehicles patent activity. To implement this, we built a Causal Loop Diagram (CLD), which represents the elements of a system including its relationships and feedback dynamics [Zemke, 2001]. This method has been used for more than 30 years as a part of the Systems Thinking methodology [Forrester, 1961]. It envisions the organization as a system made up of individual elements, which creates a synergy effect. Using Vensim sof tware [Ventana Systems Inc., 2006], we constructed a Causal Loop Diagram for hybrid vehicles as shown in Figure 1.

The greater the advances in hybrid vehicles, the higher the number of patents issued. Competition for market share will stimulate investments in new tech-

\section{Fig. 1. Causal loop diagram for hybrid vehicles}

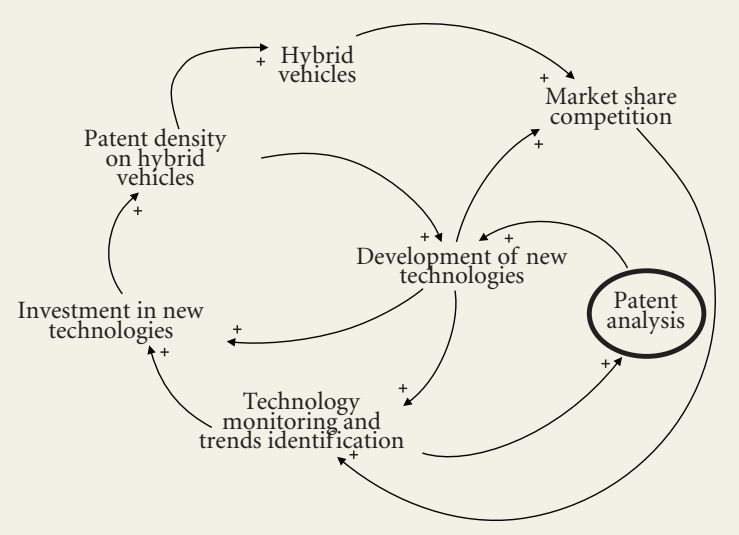

Source: compiled by the authors using the Vensim software [Ventana Systems Inc., 2006].

It should be mentioned that Toyota Motor Co. is the official English translation of the Japanese, Jidosha Kabushiki Kaisha [Toyota Motor Corporation, 2008]. Henceforth, in this paper we refer to this company by the English name. 
nologies throughout the value chain - from leading companies to 'follower' companies. We will show below how collaborative efforts among companies in this field are key to succeed.

Patent analysis is a form of Competitive Technological Intelligence (CTI), which is applied to monitor the competitive and technological environment and to guide decisions regarding research, development and innovation activities.

In this paper, we develop a methodology for analysing patent activity which extends CTI and builds upon a previous study by the authors [Rodríguez, Esquivel, 2013]. The latter study revealed valuable insights about the technological advances protected by patents in the domain of hybrid vehicles. Additionally, it provides evidence that companies with a higher patent activity also have a strong focus on collaborative technology development.

The aim of this study is to support organizations in the field by identifying - in terms of patent density - the global research areas and emphasis of research categories (according to standard patent classifications), the top patenting organizations, the joint patents of the organizations with the highest patent activity, their technology collaboration efforts, patenting activity according to the type of hybrid vehicle and alternative energy sources, and finally, the most recent patents of top organizations regarding previous results.

The remainder of this paper is organized as follows. Section 2 reviews the literature on renewable energies, hybrid vehicles, and competitive technological intelligence. Section 3 describes the methodology used, and Section 4 presents the main findings. Finally, the conclusions, recommendations, and limitations of the study are presented in Section 5.

\section{Literature Review}

\section{Renewable energy and hybrid vehicles}

Energy problems caused by the exhaustion of fossil fuels have led to the advancement of green technologies, including mechanisms to be implemented in new vehicle systems.

\section{Renewable energies}

Renewable sources, such as wind power, geothermal heat, biomass, hydrothermal, and solar, are increasingly applied for industry and domestic purposes [Rodríguez, Esquivel, 2013] and their use in large and small-scale implementations is becoming increasingly important.

There is a clear need to develop intelligent power management systems to optimize the use of energy and reduce energy consumption. These systems are needed to control many applications, including electric systems in vehicles and hybrid vehicles [Zhou et al., 2014]. According to Sewe and León [Sewe, León, 2010], the most popular alternative energy sources are: solar, wind, biomass, geothermal, and hydraulic. To reduce the negative impact of vehicle emissions, hydrogen, natural gas, ethanol, methanol, biogas, and gasoil energy sources can be used [Momoh, Omoigui, 2009]. Additionally, solar energy represents an important possibility for the propulsion of hybrid vehicles [Khan, 1994]. These elements were considered during the analysis. As we show later, the results obtained indicate that hydrogen and solar energy have the highest activity in patents. In light of this, we undertook a special analysis to identify the patent applicants working with different types of alternative fuels.

\section{Hybrid vehicles and hybrid electric vehicles (HEV)}

This section delineates the main characteristics of hybrid vehicles, including electric ones. Hybrid vehicles are vehicles with two sources of propulsion. The primary source is the combustion engine, while the secondary source is the high-voltage battery. The latter is typically an electric motor, although it can be any other renewable source [Urdiales, Limón, 2009]. The use of hybrid propulsion methods means that carbon emissions can be reduced. The most successful hybrid vehicle configuration is the hybrid electric vehicle which combines the internal combustion engine with an electric motor.

Hybrid vehicles are an increasingly important factor for protecting the environment. The evidence for this has been discussed for more than a decade [Boesel, 2013]. As pointed out above, one major trend in this market is the increase in research and development $(\mathrm{R} \& \mathrm{D})$ due to new state initiatives for hybrid vehicles [TechNavio 2014]. 
Fig. 2. Parallel hybrid system

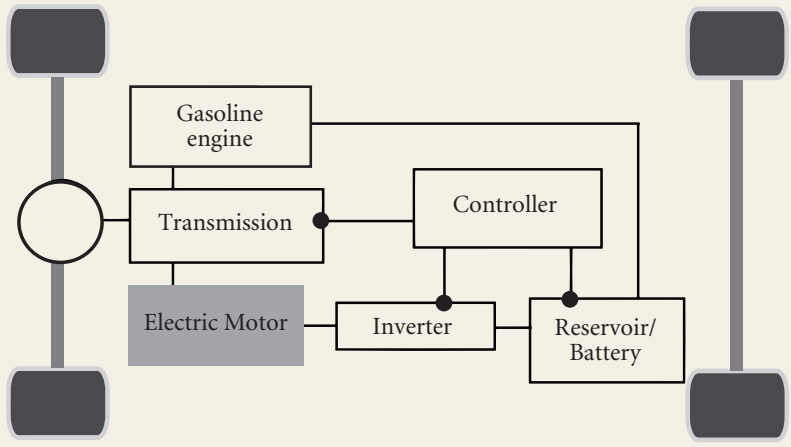

Source: [Emadi, 2005, p. 23].

Three types of hybrid vehicles can be identified, as described below [Sewe, León, 2010; Emadi, 2005]:

(1) Parallel hybrid (Fig. 2). These vehicles are the most economical and popular on the market. Their architecture is widely used because the propulsion architecture is similar to a conventional vehicle. The hybrid system serves as a kind of add-on structure [Emadi, 2005].

(2) Series Hybrid (Fig. 3). As Emadi [Emadi, 2005] highlights, the series hybrid propulsion system has yet to find acceptance in gasoline and diesel electric passenger sedans and light trucks. This may be partly because the architecture here is heavier and more expensive than its parallel and combination architecture alternatives.

(3) Series-Parallel Hybrid (Fig. 4). Emadi [Emadi, 2005] states that the primary three advantages of this architecture are: i) the relatively simple transmission mechanism; ii) the engine speed can be confined to a narrow operating range through control of the motor generator $\mathrm{A}$; and iii) the engine can be further downsized. The Toyota Prius is a typical example of this kind of architecture.

\section{Competitive technological intelligence}

Competitive Intelligence is a systematic and ethical process for gathering and analyzing information about the activities and general business trends to improve the performance of the involved organization [Moretti, 2004]. Once analysed, the information provides data on the behaviour, strengths, and weaknesses of competitors, as well as technological and other issues concerning the competitive environment to establish parameters for innovation areas. Competitive intelligence is a useful tool to understand the direction in which technologies are evolving [Calof et al., 2015].

The society of Strategic Competitive Intelligence Professionals (SCIP) defines competitive intelligence as an ethical and systematic process to find information with specific tasks, such as analysing and managing information that may affect

Fig. 3. Series hybrid system

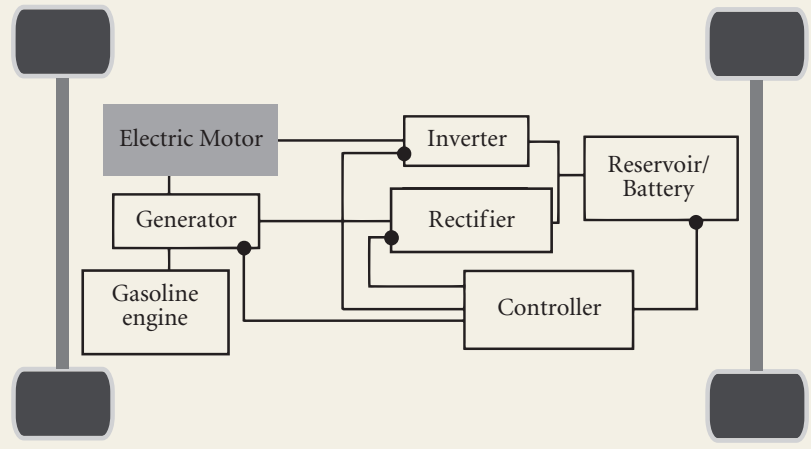

Source: [Emadi, 2005, p. 29]. 
Fig. 4. Series-parallel hybrid system

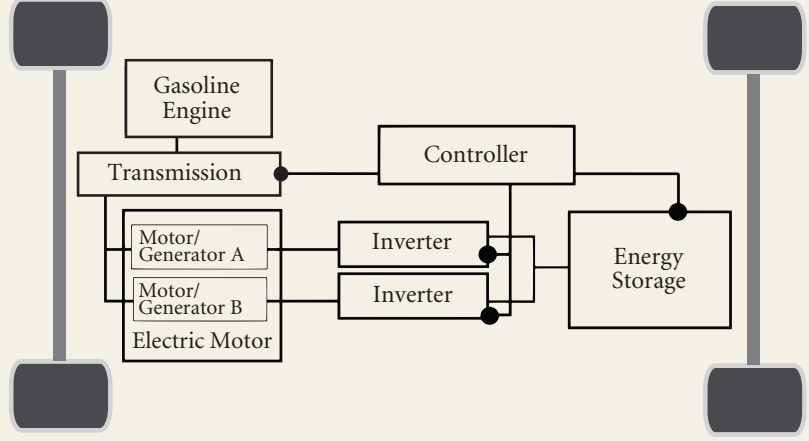

Source: [Emadi, 2005, p. 31].

the plans, decisions or operations of the company with the purpose of acting in a relevant, accurate, specific, and timely manner [Brody, 2008].

Similarly, Van Brakel [Van Brakel, 2005] defines competitive intelligence as a business discipline applied by companies and countries as a means to improve their competitiveness through the better use of information. One of the main benefits of this activity is to reduce risk when making decisions and to identify opportunities and threats that exist in the competitive marketplace.

Additionally, Rodríguez and Tello [Rodríguez, Tello, 2012] include technology in the concept of competitive intelligence and define it as Competitive Technological Intelligence (CTI): the process for monitoring the competitive and technological environment of an organization to support strategic decisions, especially those related to market, innovation, product design, and research and development. Companies should constantly innovate in the products and services they offer because consumer needs change [Rodríguez, Esquivel, 2013]. In particular, CTI provides a methodology to systematically monitor competitors, research entities, and universities to better understand R\&D advances.

\section{Patent analysis}

CTI is developed through an analysis of primary (field research, including interviews) and secondary (articles, patents, reports, news) official information. Patent analysis is a critical element of CTI in research extensive fields, such as hybrid vehicles. The number of patent applications and patents granted are valuable statistics for understanding inventive activity of a given technology market [Streltsova, 2014]. Insights from patents reveal the leading companies, their research areas, the claims of intellectual protection, and emerging areas. Thus, actionable knowledge is obtained to identify opportunities or threats to innovation [Rodríguez, 2003]. Patent analysis also provides a means to predict product maturity and market trends [Trappey et al., 2010]. Open patent data can illustrate research trends and future advances, and can also support corporate strategic decision making, the R\&D sphere, and policy making [Denisova et al., 2011].

To safeguard their exclusive right to their invention, which then allows them to own the exclusive rights to produce and market it, organizations or individuals can protect it through a patent. Thus, patent analysis is of ten used to monitor the R\&D portfolios of competitors, and to analyse the global evolution of in dustries and companies [ Lai et al., 2006]. Moreover, it also provides knowledge to reduce the duplication of inventions, avoid patent infringement, and identify technologies to be licensed.

Patent analysis is frequently used by the most innovative companies to support decisions about mergers and acquisitions, determine competitors' areas of expertise, identify competitive trends (including the prioritization of R\&D efforts), and finally, to strengthen the overall strategic planning process [Ramos, 2011].

There are several methods for patent analysis [Trappey et al., 2011]. These include patent mapping, clustering, and life cycle analysis. Data mining tools are of ten used in patent analysis because they facilitate the processing of hundreds of bibliographic record fields (e.g. title, applicant, author, country). Besides, 
specialized sof tware is required: several options exist on the market, including Gold Fire Innovator, Matheo Patent, Patent Insight Pro, and Vantage Point. Data mining sof tware enable researchers to collect, synthesize, analyse, classify, and display information more efficiently. It is important to do a detailed analysis in order to determine which sof tware best fits a specific project's requirements [Lugo, 2008]. Interpretation of patent maps requires an expert of the field; this operation cannot be fully automated regardless of the quality of the software [Lee et al., 2006].

\section{Patent analysis of hybrid vehicles}

Numerous patent analysis studies have been made in this field since the early 2000s [Ranaei et al., 2014]. However, only a few studies have applied this tool for hybrid vehicles. Porter and his colleagues [Porter et al., 2015] applied a patent analysis tool as an input to a forecasting exercise on hybrid and electric vehicles. The authors analysed patent information from 2000 to 2012 through the Derwent World Patent Index, via Thomson Innovation. Results showed that intellectual property production on HEVs is led by the US, Japan, and Germany. On the other hand, Kwon and Jeong [Kwon, Jeong, 2013] analysed patent applications for green cars in the United States, Japan, Europe, Korea, and PCT international applications from 2000 to 2011. Patent information was searched for using WIPS (www.wipsglobal.com). The scope of the analysis on green car patents included electric vehicles (EV), plug-in hybrid electric vehicles (HEV), fuel cell electric vehicles (FCEV), and clean diesel vehicles (CDV). The US and Japan demonstrated the most prominence in hybrid vehicles research, followed by Korea.

Additionally, Ranaei et al. [Ranaei et al., 2014] carried out a patent analysis on low emission vehicles. This study covered the time period from 1994 to 2013, and analysed patents related to battery electric vehicles (BEV), HEVs, hydrogen vehicles $(\mathrm{HV})$, and fuel cell vehicles (FCV). Its authors calculated the growth technology curves. As a result, they estimated a steady increase in low emission technologies, including hybrid and battery electronic vehicles. However, the authors predict that this industry could reach a saturation point in a few decades.

We will further discuss the main findings of the two mentioned studies on hybrid vehicles [Kwon, Jeong, 2013; Ranaei et al., 2014], then we present our results (section 4 below).

\section{Derwent innovations index}

The Derwent Innovations Index is a reference for many companies and research entities. It belongs to Thomson Reuters, a private database that contains patent applications and grants covering over 14.3 million inventions from 40 patentissuing authorities worldwide. Tracking information for over 40 years, it includes information from the European Patent Office, Japanese Patent Office, the US Patent and Trademark Office, PCT (WO), etc. The Derwent Innovations Index is a highly valuable resource to better understand technological progress over time [Thomson Reuters, 2014b]. Information from patents, including that in Derwent, is an excellent way to analyse the behaviour of a given technology [Mogee, 1991].

\section{Methodology}

The main purpose of this study is to develop a patent study on hybrid vehicles as an initial approach to identify the patent density in this field and the collaborative efforts of organizations with the highest patent activity, including identifying these organizations' strategic partners and the most recent patents. This paper contributes to ongoing research on hybrid vehicles with the aim of adding value to organizations interested in this field.

This study was developed by the research group on Competitive Technical Intelligence of Tecnológico de Monterrey, Campus Monterrey. Tecnológico de Monterrey is a prestigious private institute with over 30 campuses in Mexico, over 100,000 students, and more than 8,000 teachers and liaison of fices in North America, Europe, and Asia. The headquarters are located on Monterrey Campus, where the main research efforts of this Institute are performed.

Based on the Systems Engineering approach, the study developed a scientometric methodology to examine the technology advancements through patent analysis. Figure 5 illustrates this methodology, consisting of interrelated phases through 


\section{Fig. 5. Methodology for a systemic technology patent analysis}

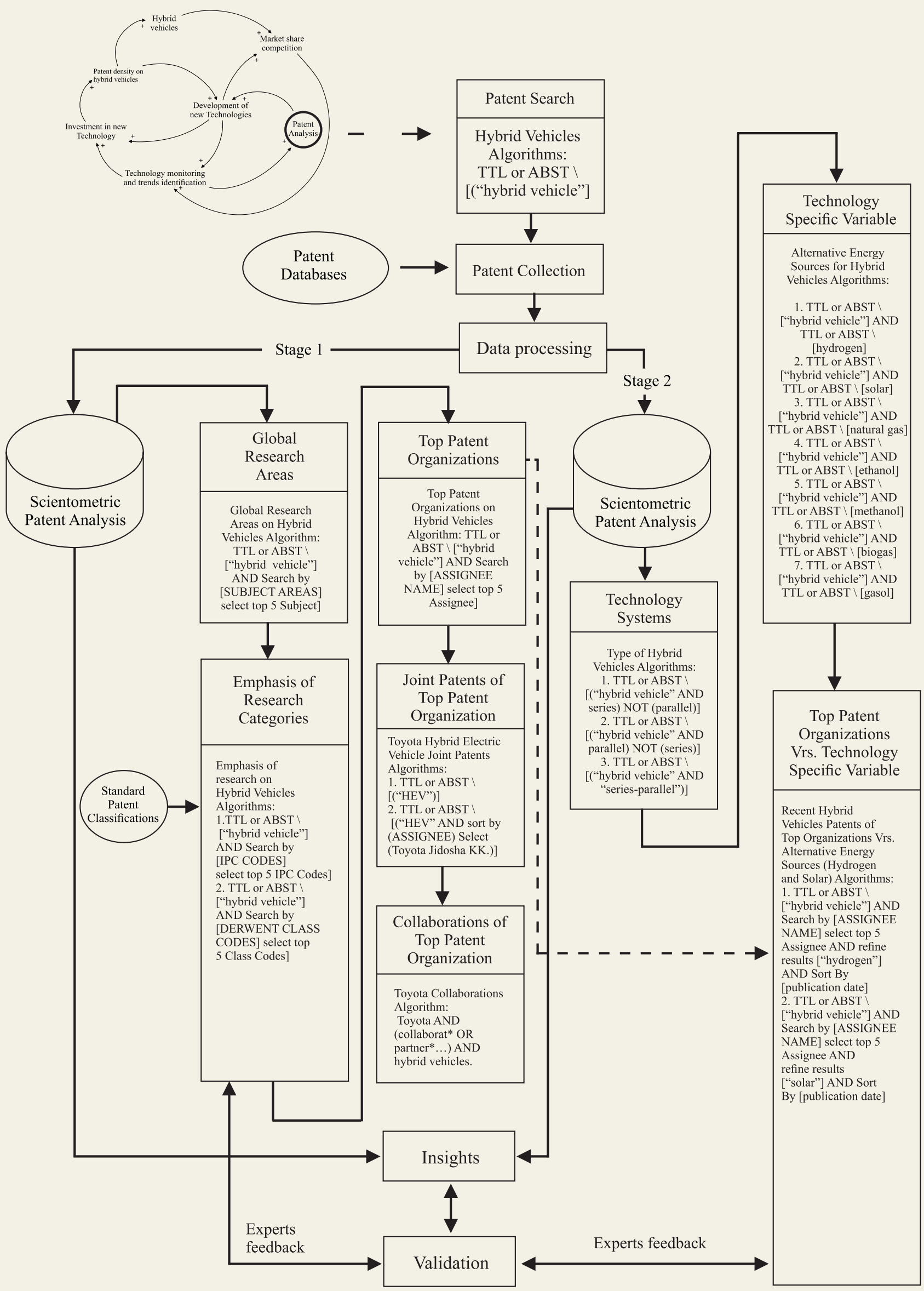


a systematic process. The first stage consists of an initial patent search about the technology examined. This information could be collected from different patent databases such as Espacenet, USPTO, etc. Next, the data are processed to eliminate duplicates and irrelevant information. The second stage entails a scientometric patent analysis using special sof tware. This activity is developed in two phases. The first phase identifies the key global research areas, emphasizes research categories (taking into account the different standard patent classifications), top patent organizations, joint patents of the organization identified with the highest patenting activity, and their technological collaboration efforts. The second phase identifies the patenting activity according to different technology systems: in this case, the type of hybrid vehicle. A posterior analysis is made to integrate a specific variable depending on the purpose of the study; in this case, the types of alternative energy sources were taken into account. Subsequently, a specific analysis of recent patents based on the previous variable is made considering leading organizations. Finally, it is important to emphasize that feedback from experts in the field is required throughout the whole process. Moreover, a final validation should be made to acquire new perspectives and enriching insights.

We developed a case study of hybrid vehicles, applying the Derwent Innovations Index of the ISI Web of Knowledge [Thomson Reuters, 2014a]. As shown in the Introduction, we created a Causal Loop Diagram to delineate the different parts making up the system of this study. Under this approach, a two-stage process was performed. The first included determining the number of patents for hybrid vehicles. For this, we took the time period from 2000 to October 31, 2014. Data collection was based on patents containing the term 'hybrid vehicle' in the field 'Topic' (title and abstract).

A total of 40,023 patents were obtained. These data were processed to eliminate duplicates, irrelevant information and standardize fields such as organizations' names. Next, the predominant global research areas were identified taking into account the Derwent classification. Subsequently, the emphasis of research was determined considering the International Patent Classifications (IPCs) and the Derwent Class Codes (DCCs). The leading patent applicant organizations were also identified.

The results indicate that automotive companies are the major players for technology inventions. Other entities (e.g., universities, research centres, and government agencies) that undertake their own R\&D in this area have a lower impact in terms of patent applications. In this context, joint patents and technological collaborations of the leading patenting companies in the energy sector were analysed. To accomplish this aim, internet-based research identified the collaboration agreements in the energy sector. All the information gathered was processed to eliminate irrelevant information and prepare it for the analyses. The second stage performed specific analyses, and determined the patents corresponding to the different types of hybrid vehicles (parallel, series, and series-parallel) to then identify renewable energies. Recent patents of the leading patent applicant companies were identified according to the alternative energy sources with the highest number of patents. Finally, all the information was analysed and relevant insights were generated. The findings of this research were validated by experts in the field. Their feedback was useful and led to new perspectives and knowledge.

In the next section, we present the results of the case study.

\section{Discussion and Results}

\section{First stage}

\section{Global research areas}

A total of 40,023 patents were obtained on 'hybrid vehicles'. As mentioned previously, the first stage of this analysis aimed to identify the general focus of research; to this end, we used the standard Derwent classification. As a result, the following patent global research areas were determined: Engineering (39,094 patents); Transportation (37,303 patents); Energy and Fuels (18,086 patents); Instruments and Instrumentation (15,860 patents); Computer Science (7,347 patents). The results are shown in Figure 6. 


\section{Fig. 6. Number of patents by key global research areas in the field of} hybrid vehicles, 2000-2014, based on the Derwent classification*

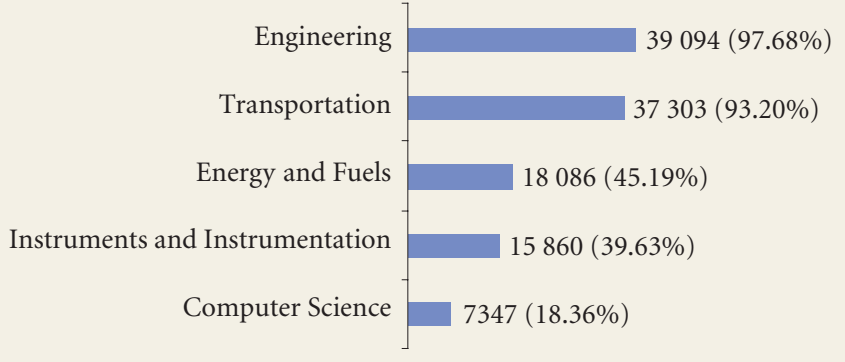

${ }^{*}$ As patents could belong to more than one area, the sum of the percentages exceeds $100 \%$.

Source: authors' calculations.

Emphasis of research based on the top international patent classification (IPC)

The IPC, established by the Strasbourg Agreement of 1971, provides a hierarchical system of language-independent symbols for the classification of patents and utility models according to the different areas of technology to which they pertain. The IPC divides technology into eight sections with approximately 70,000 sub-divisions. Each sub-division has a symbol consisting of Arabic numerals and letters of the Latin alphabet.

An IPC with more digits (numerals and letters) is more specific. The minimum number of digits is four, providing only a broad patent classification. Patents can belong to more than one IPC. The development of hybrid vehicles implies the use of technologies from a diversity of areas, so a high technical diversity is present as shown by Kwon and Jeong [Kwon, Jeong, 2013].

In our study, we identified the leading categories of research based on detailed IPCs. The top five main IPCs of hybrid vehicles are shown in Table 1.

The results indicate that research is mainly focused on control systems for hybrid vehicles, as illustrated by IPC B60W-020/00, followed by electric vehicle propulsion systems (represented by IPC B60L). Insights from Kwon and Jeong [Kwon, Jeong, 2013] indicate a similar trend: electric vehicle propulsion systems (B60L), power transmission systems (B60K), and control systems specially adapted for hybrid electric vehicles (B60W).

Emphasis of research based on the top Derwent Class Codes (DCC)

We also determined the patent categories based on the standard Derwent Innovations Index classification. DCCs classify patent documents into 'Chemical Sections' (AM), 'Engineering Sections' (PQ), and 'Electrical and Electronic Sections' (SX). The Top 5 DCCs are shown in Table 2.

\begin{tabular}{|l|c|c|c|}
\hline \multicolumn{1}{|c|}{ Table 1. Top patent categories of hybrid vehicles based on the IPC-WIPO system } \\
\hline IPC & Patents & $\begin{array}{c}\text { Share } \\
(\%)\end{array}$ & Description* \\
\hline B60W- 020/00 & 9141 & 22.84 & $\begin{array}{l}\text { Control systems specially adapted for hybrid vehicles, i.e., vehicles having two or more prime } \\
\text { movers of more than one type, e.g., electrical and internal combustion motors, all used for } \\
\text { vehicle propulsion }\end{array}$ \\
\hline B60L- 011/14 & 6861 & 17.14 & $\begin{array}{l}\text { Electric propulsion with power supplied within the vehicle (B60L 8/00, B60L 13/00 take } \\
\text { precedence; arrangements or mounting of prime movers consisting of electric motors and } \\
\text { internal combustion engines for mutual or common propulsion with provisions for direct } \\
\text { mechanical propulsion }\end{array}$ \\
\hline B60W-010/08 & 6126 & 15.31 & $\begin{array}{l}\text { Conjoined control of vehicle sub-units of different types or different functions (for the } \\
\text { propulsion of purely electrically propelled vehicles with power supplied within the vehicle } \\
\text { including control of electric propulsion units, e.g. motors or generators }\end{array}$ \\
\hline B60K-006/00 & 5685 & 14.20 & $\begin{array}{l}\text { Arrangement or mounting of plural diverse prime-movers for mutual or common } \\
\text { propulsion, e.g., hybrid propulsion systems comprising electric motors and internal } \\
\text { combustion engines }\end{array}$ \\
\hline B60W-010/06 & 5182 & 12.95 & $\begin{array}{l}\text { Conjoined control of vehicle sub-units of different types or different functions (for the } \\
\text { propulsion of purely electrically propelled vehicles with power supplied within the vehicle, } \\
\text { including the control of combustion engines }\end{array}$ \\
\hline \\
* The data in column 4 are from Section B - Performing Operations; Transporting. \\
Source: [WIPO, 2014b].
\end{tabular}




\section{Table 2. Top patent categories based on the Derwent Class Codes}

\begin{tabular}{|c|c|c|c|}
\hline DCC & Patents & $\begin{array}{c}\text { Share } \\
(\%)\end{array}$ & \multicolumn{1}{|c|}{ Description } \\
\hline $\mathrm{X} 21$ & 35296 & 88.19 & $\begin{array}{l}\text { Electric Vehicles (B60L). Electric cars, trolley buses. Propulsion, braking. Power supply lines, current } \\
\text { collectors. Traction batteries. Control equipment. }\end{array}$ \\
\hline $\mathrm{X} 22$ & 19624 & 49.03 & $\begin{array}{l}\text { Automotive Electrics (F02P). Vehicle accessories. Vehicle lighting. IC engine ignition. IC engine } \\
\text { controllers. Batteries and charging. Starting motors, and generators. Engine and vehicle } \\
\text { instrumentation. Non-engine related controllers e.g., transmissions, brakes. }\end{array}$ \\
\hline $\mathrm{X} 16$ & 11618 & 29.03 & $\begin{array}{l}\text { Electrochemical Storage (H01M). Primary, secondary, and fuel cells and batteries. Battery chargers. } \\
\text { Non-electrochemical storage of electric energy. }\end{array}$ \\
\hline T01 & 7415 & 18.53 & $\begin{array}{l}\text { Digital Computers (G06C-F). Electronic data processors, interfaces, and program control. Mechanical } \\
\text { digital computers. }\end{array}$ \\
\hline L03 & 4977 & 12.44 & $\begin{array}{l}\text { Electro-(in)organic, chemical features of conductors, resistors, magnets, capacitors and switches, } \\
\text { electric discharge lamps, semiconductors and other materials, batteries, accumulators, and thermo- } \\
\text { electric devices, including fuel cells, magnetic recording media, radiation emission devices, liquid } \\
\text { crystals, and basic electric elements. }\end{array}$ \\
& * The data in column 4 are from Derwent Innovation Index. \\
Source: [Thomson Reuters, 2009].
\end{tabular}

As with the IPC analysis, patents can also belong simultaneously to multiple categories of the DCC. The general classifications X, T, and L are the most important; in this system, these classifications correspond to the following topics:

- Electrical and electronic sections (S-X):

- X: Electric Power Engineering

$-\mathrm{T}$ : Computing and control

- Chemical sections (A-M):

- L: Refractories, ceramics, cement and electro-(in)organics.

Although the IPCs and DCCs have different underlying principles, the results of both analyses were similar, particularly regarding the inclusion of electric power engineering, computing, and control systems.

\section{Top patent organizations}

An analysis was performed to determine the entities with the highest number of patents. Results indicated that automotive companies have more technological advances in hybrid vehicles compared to academic institutions. As shown in Figure 7, the top three patent recipients were: Toyota (13,266 patents), Nissan (2,397 patents), and Nippondenso (1,956 patents).

These results confirm the findings obtained by Kwon and Jeong [Kwon, Jeong, 2013]: Toyota Motor is the leader for patents in the field of hybrid vehicles, while Hyundai Motor and Honda Motor present a near-average patent density.

In addition, our results are also comparable to the findings of Ranaei et al. [Ranaei et al., 2014] where in terms of battery electric vehicles (BEV), hybrid electric vehicles (HEV), and patents related to hydrogen vehicles (HV) or fuel cell vehicles (FCV), Toyota led due to its highest patent activity, followed by Nissan and Honda.

\section{Toyota joint patents}

A specific analysis on HEV of the top patenting company was made, in this case it was Toyota. We first identified the HEV patents between 2000 and 2014. Out of a total of 1,883 patents, 45 belonged to Toyota. Next, we analysed the joint Toyota patents to identify partnerships. Our results are presented in Table 3.

\section{Fig. 7. Number of patents in the field of hybrid vehicles received by the patent-leading companies in 2000-2014}

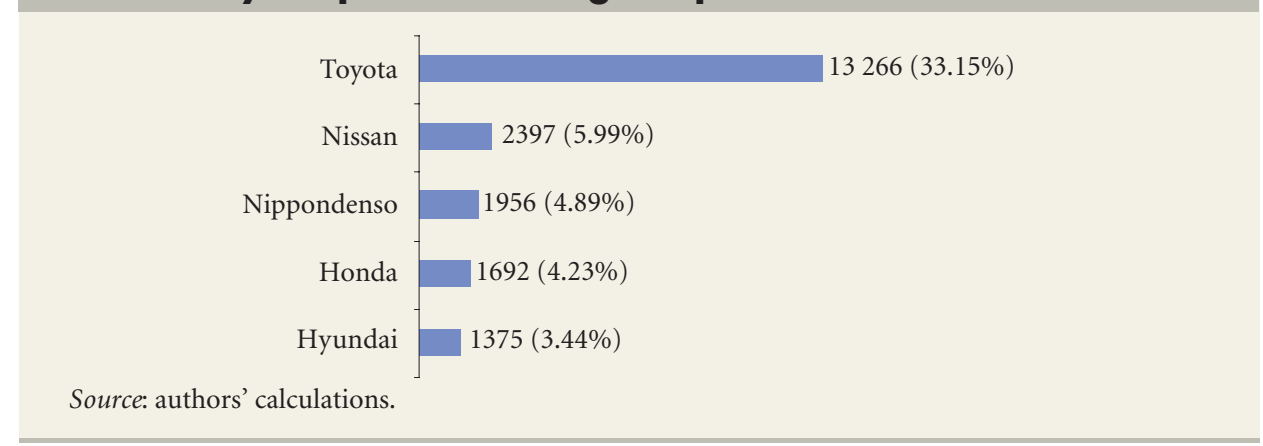




\section{Table 3. Toyota Joint Patents on HEVs}

\begin{tabular}{|c|c|c|}
\hline Toyota's Partner & $\mathbf{N}^{\circ}$ Patent ${ }^{\star}$ & Publication Date ${ }^{\star}$ \\
\hline Sanyo Electric Co. Ltd. (Saol-C) & JP2014093127-A & 19.05.2014 \\
\hline Sanyo Electric Co. Ltd. (Saol-C) & JP2013157104-A & 15.08 .2013 \\
\hline Sanyo Electric Co. Ltd. (Saol-C) & JP2013157130-A & 15.08 .2013 \\
\hline Aisin Seiki KK (AISE-C) & JP2011244529-A & 01.12 .2011 \\
\hline Yokohama Nat. Univ. (Uyyo-Non-standard) & JP2011097740-A & 12.05 .2011 \\
\hline Fujitsu Denso Ltd. (FUTD-C) & JP2010102944-A & 06.05 .2010 \\
\hline Aisin A.W. Co. Ltd. (AISW-C) & JP2009067256-A & 02.04 .2009 \\
\hline Matsushita Denki Sangyo KK (MATU-C) & JP2004088819-A & 18.03.2004 \\
\hline Fuji Electrochemical Co. Ltd. (FJIC-C) & JP2004088878-A & 18.03.2004 \\
\hline Matsushita Electric Ind. Co. Ltd. (MATU-C) & \multirow{3}{*}{ JP2003017142-A } & \multirow{3}{*}{17.01 .2003} \\
\hline Matsushita Denki Sangyo KK (MATU-C) & & \\
\hline Panasonic Co. (MATU-C) & & \\
\hline Matsushita Electric Ind. Co. Ltd. (MATU-C) & \multirow{2}{*}{ JP2003079051-A } & \multirow{2}{*}{ 14.03.2003 } \\
\hline Matsushita Denki Sangyo KK (MATU-C) & & \\
\hline Matsushita Electric Ind. Co. Ltd. (MATU-C) & \multirow{2}{*}{ JP2003004822-A } & \multirow{2}{*}{08.01 .2003} \\
\hline Matsushita Denki Sangyo KK (MATU-C) & & \\
\hline Nippondenso Co. Ltd. (NPDE-C) & \multirow{2}{*}{ JP2003032907-A } & \multirow{2}{*}{31.01 .2003} \\
\hline Denso Corp. (NPDE-C) & & \\
\hline Matsushita Electric Ind. Co. Ltd. (MATU-C) & \multirow{2}{*}{ JP2003007271-A } & \multirow{2}{*}{10.01 .2003} \\
\hline Matsushita Denki Sangyo KK (MATU-C) & & \\
\hline Matsushita Electric Ind. Co. Ltd. (MATU-C) & \multirow{2}{*}{ JP2003022837-A } & \multirow{2}{*}{24.01 .2003} \\
\hline Matsushita Denki Sangyo KK (MATU-C) & & \\
\hline Matsushita Electric Ind. Co. Ltd. (MATU-C) & \multirow{3}{*}{ JP2002367684-A } & \multirow{3}{*}{20.12 .2002} \\
\hline Matsushita Denki Sangyo KK (MATU-C) & & \\
\hline Panasonic Co. (MATU-C) & & \\
\hline Nippondenso Co. Ltd. (NPDE-C) & JP2001352688-A & 21.12 .2001 \\
\hline Matsushita Electric Ind. Co. Ltd. (MATU-C) & \multirow{2}{*}{ JP2001297801-A } & \multirow{2}{*}{26.10 .2001} \\
\hline Matsushita Denki Sangyo KK (MATU-C) & & \\
\hline Matsushita Electric Ind. Co. Ltd. (MATU-C) & \multirow{3}{*}{ JP2002015781-A } & \multirow{3}{*}{ 18.01.2002 } \\
\hline Matsushita Denki Sangyo KK (MATU-C) & & \\
\hline Panasonic Co. (MATU-C) & & \\
\hline Matsushita Electric Ind. Co. Ltd. (MATU-C) & \multirow{3}{*}{ JP2001313019-A } & \multirow{3}{*}{09.11 .2001} \\
\hline Matsushita Denki Sangyo KK (MATU-C) & & \\
\hline Panasonic Co. (MATU-C) & & \\
\hline Matsushita Electric Ind. Co. Ltd. (MATU-C) & JP2001314041-A & 09.11 .2001 \\
\hline
\end{tabular}

Toyota jointly developed and protected a wide range of technologies related to HEVs from 2000 to 2014 with various companies including: Panasonic Corporation, Sanyo, Asin Seiki Co. Ltd., Yokohama National University, Fujitsu Denso, Aisin A.W. Co. Ltd., Matsushita Denki Sangyo, Fuji Electrochemical, Matsushita Electric, and Nippondenso (which belongs to Toyota). These results will be backed up in the next section, which examines the active collaborations Toyota maintains in the sphere of technological R\&D on hybrid vehicles.

Technological collaborations of the top patenting organization

Collaboration in the industry to reach a leading technology position is increasing worldwide, including for automotive companies. From the broad perspective of co-evolution of the vehicle sector, the following actors are involved: car manufacturers, engine component suppliers, car users, car repair shops, sales persons, journalists, universities, research centres, banks, venture capitalists, shareholders, and policy makers [Dijk, Yarime, 2010].

Unquestionably, car manufacturers play an influential role in this co-evolution. As shown in the previous section, Toyota Motor Company leads on patenting activity for hybrid vehicles. In terms of collaboration and patent domain, we first highlight three main issues from Kwon and Jeong [Kwon, Jeong, 2013]: 
a) Toyota Motor became more competitive due to open innovation in the last five years; b) Toyota Motor acquired significantly more patents in hybrid vehicles compared to in other domains; c) Toyota Motor, together with Hyundai Motor and Ford Global Technologies, became the R\&D leaders thanks to their international collaboration networks.

Considering the importance of Toyota Motor, we carried out an in-depth analysis of its collaboration initiatives in the field of hybrid vehicles (Table 4).

In addition, Toyota has established a diversity of collaborations a long time ago. For example, the collaboration between Ford and Toyota Motor Corporation in 2005 enabled the co-development of hybrid cars and the sale of Ford vehicles in Japan. In conclusion, Toyota Motor's leadership in the market of hybrid vehicles is the result of a significant balance between their own developments and those produced through their strong collaborative technology network. Toyota currently remains the leader in developing hybrid models of cars. For example, in January 2014, they launched the completely redesigned 'Voxy' minivan through the Netz dealers in Japan, and the completely redesigned 'Noah' minivan through Toyota Corolla dealers. Monthly sales targets for Japan are 4,600 units of 'Voxy' and 3,400 units of 'Noah' [Toyota Motor Corporation, 2014].

\section{Second stage}

\section{Patent activity according to the type of hybrid vehicle}

The starting point of the second stage was to identify the most active types of hybrid vehicles in terms of patents. For this purpose, we considered the classification previously presented on parallel, series and series-parallel. Analysing the total of 40,023 patents, the results obtained indicate a predominance of parallel hybrids (1,475 patents), as shown in Figure 8.

\section{Patent activity according to alternative energy sources}

For the purpose of this research, it was also important to identify alternative energy sources with the highest patenting activity.

\section{Table 4. Recent collaboration efforts of Toyota Motor Co. Ltd. in the field of hybrid vehicles}

\begin{tabular}{|c|c|c|}
\hline Partner Organization & Year & Objective \\
\hline $\begin{array}{l}\text { The U.S. Department of Energy's } \\
\text { (DOE) National Renewable Energy } \\
\text { Laboratory (NREL) }\end{array}$ & 2013 & $\begin{array}{l}\text { To enhance NREL's research related to hydrogen fuel, renewable } \\
\text { hydrogen production, and vehicle performance. For this task, the NREL } \\
\text { received four fuel cell hybrid vehicles - advanced (FCHV-adv) on loan } \\
\text { from Toyota Motor Co. through a two-year cooperative research and } \\
\text { development agreement. }\end{array}$ \\
\hline BMW Group ${ }^{a}$ & 2013 & $\begin{array}{l}\text { Joint development of a fuel cell system, architecture and components for } \\
\text { a sport vehicle, and R\&D on lightweight technologies. } \\
\text { Both entities also signed a binding agreement to start collaborative } \\
\text { research on lithium-air batteries including a post-lithium-battery solution. }\end{array}$ \\
\hline $\begin{array}{l}\text { Nissan Motor Co., Ltd. } \\
\text { Honda Motor Co., Ltd. }^{\mathrm{a}} \\
\text { Mitsubishi Motors Corporation }^{\mathrm{a}}\end{array}$ & 2013 & $\begin{array}{l}\text { To promote the installation and use of chargers for electric-powered } \\
\text { vehicles (PHVs, PHEVs, EVs), creating a charging network service more } \\
\text { convenient for drivers in Japan. A new company: Nippon Charge Service } \\
\text { was created for this task. }\end{array}$ \\
\hline $\begin{array}{l}\text { Energy Duke } \\
\text { Energy Systems Network }\end{array}$ & 2012 & $\begin{array}{l}\text { To provide a simple and affordable smart grid communication protocol } \\
\text { between the vehicle, the charging station, and the utility company, to } \\
\text { effectively manage hybrid's vehicle charging. The pilot project involves } 5 \\
\text { Prius Toyota plug-in hybrid vehicles driven by Duke Energy customers. }\end{array}$ \\
\hline $\begin{array}{l}\text { Osaka Gas Co., Ltd. } \\
\text { Chofu Seisakusho Co., Ltd. } \\
\text { Aisin Seiki Co., Ltd. }\end{array}$ & 2012 & $\begin{array}{l}\text { To develop a residential use of solid oxide fuel cell (SOFC) co-generation } \\
\text { system (SOFC system). The resulting product, ENE-FARM Type S, } \\
\text { achieves a power generation efficiency of } 46.5 \% \text { for a residential-use fuel } \\
\text { cell. }\end{array}$ \\
\hline Ford ${ }^{\mathrm{b}}$ & 2011 & $\begin{array}{l}\text { To develop a hybrid-electric powertrain earmarked specifically for rear- } \\
\text { wheel-drive light pickup trucks and SUVs. However, after a two-year } \\
\text { 'feasibility study,' they decided to end this hybrid collaboration before it } \\
\text { starts. }\end{array}$ \\
\hline Tesla Motors ${ }^{c}$ & 2010 & $\begin{array}{l}\text { To develop production systems, EVs as well as providing engineering } \\
\text { support. Toyota acquired a } 3 \% \text { equity stake of Tesla Motors. Tesla Motors } \\
\text { will help Toyota create a plug-in EV, developing an electric powertrain, } \\
\text { etc. Toyota will help Tesla by providing engineering and production } \\
\text { expertise. }\end{array}$ \\
\hline $\begin{array}{l}\text { Kajima Corporation }^{\mathrm{a}} \\
\text { Mitsubishi Heavy Industries, Ltd. }^{\mathrm{a}} \\
\text { Nippon Oil Corporation } \\
\text { Sapporo Engineering Co., Ltd. }{ }^{\mathrm{a}} \\
\text { Toray Industries, Inc.. }\end{array}$ & 2009 & $\begin{array}{l}\text { To establish a joint venture company in order to develop a next-generation } \\
\text { cellulose-derived biofuel. }\end{array}$ \\
\hline
\end{tabular}




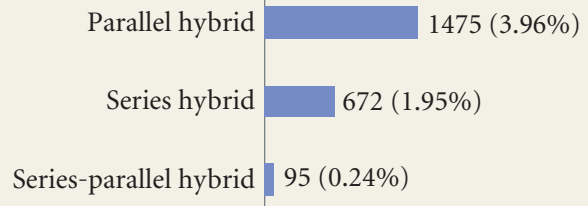

Source: authors' calculations.

Although the hybrid and electric car market is currently growing at a strong rate, manufacturers are already moving to new green technologies such as hydrogen fuel cells. The industry is looking for new energy sources more than electricity, and a steady growth is estimated in the next few years [MarketLine, 2014]. Figure 9 shows the results.

Patents involving the use of hydrogen (1,655 patents) predominate, followed by solar energy (413 patents) and natural gas (125 patents).

\section{Recent patents of the top companies in the field of alternative energy}

Considering the broad scope of the 40,023 patents obtained for 'hybrid vehicles', we further analysed the top five patenting companies and the two most important alternative energy sources: hydrogen and solar energy. For this aim, the search strategy combined the top applicants (assignee name of each patent) with the 'hydrogen' or 'solar' keyword in the 'title' and 'abstract' fields. As a result, we obtained 1009 patents. Table 5 presents the most recent of these patents.

Toyota stands out for owning the absolute majority of these recent technological advancements in the field of batteries, including a power supply device for supplying electric power to the controlled unit. On the other hand, Hyundai stands out for its patented invention related to a hands-free system for opening the trunk.

Advancements in the use of solar energy for hybrid vehicles were also investigated by considering the top five companies. A total of 56 patents were found for solar energy; the most recent of which are presented in Table 6.

In this case, the company Nippondenso has the highest patent activity, which is partly owned by Toyota. Nippondenso's current research focus is on photovoltaic power generation and power conversion and its controllers.

\section{Conclusions}

This study described the technological landscape of hybrid vehicles using a systemic patent analysis. This research is the first attempt to identify and analyse patent density for hybrid vehicles from 2000 to 2014. A total of 40,023 patents were analysed, which enabled us to conclude that the global R\&D priorities in this field include areas such as engineering (39,094 patents), transportation $(37,303$ patents), and energy and fuels (18,086 patents). Based on standard classifications, the industry's efforts are focused on IPC B60W technologies: these

\section{Fig. 9. Number of patents granted in the field of alternative energy} sources for hybrid vehicles, 2000-2014

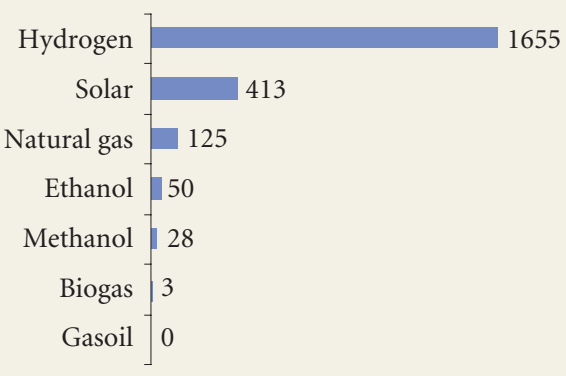


Table 5. The most recent patents granted to the top companies in the field of hydrogen

\begin{tabular}{|l|c|c|}
\hline \multicolumn{1}{|c|}{ Patent Number } & Applicant & Publication Date \\
\hline JP2014184816-A & Toyota Jidosha KK ( TOYT-C) & 02.10 .2014 \\
\hline JP2014187771-A & Toyota Jidosha KK ( TOYT-C) & 02.10 .2014 \\
\hline EP2784754-A1 & $\begin{array}{c}\text { Hyundai Motor Co. Ltd. } \\
\text { ( HYMR-C). Ltd. }\end{array}$ & 01.10 .2014 \\
\hline JP2014180960-A & Toyota Jidosha KK ( TOYT-C) & 29.09 .2014 \\
\hline JP2014167845-A & Toyota Jidosha KK ( TOYT-C). & 11.09 .2014 \\
\hline \multicolumn{2}{|l|}{ Source: Derwent Innovation Index Patent Database [Thomson Reuters, 2014b]. } \\
\hline
\end{tabular}

are the control systems specially adapted for hybrid vehicles i.e. vehicles with two or more prime movers of at least two different types [WIPO, 2014a]. Alternately, the DCC analysis indicated that patent activity mainly focuses on electric cars, trolley buses, propulsion, power supply, traction batteries, and control equipment. The patent leaders for hybrid vehicle technologies were identified as follows: Toyota Motor Co. Ltd., Nissan Motor Co. Ltd., Nippondenso Co. Ltd., Honda Motor Co. Ltd., and Hyundai Motor Co. Ltd. Moreover, we found that Toyota has developed joint patents for HEV with organizations such as Sanyo, Aisin Seiki Co. Ltd., Yokohama National University, and others. Additional results were obtained to validate the strong collaborative strategy that Toyota follows for R\&D on hybrid vehicles.

In terms of the type of hybrid vehicle researched, the parallel type predominates with 1,475 patents, followed by the serial hybrid with 672 patents. As for alternative energy sources, the most extensive research has been carried out on hydrogen with 1,655 patents, followed by solar energy with 413 patents. Natural gas ranks third (125 patents).

Finally, we analysed the leading companies and their recent patent efforts according to the top alternative energy sources. This analysis confirmed the leading position of Toyota Motor Co. Ltd., which is developing new technologies for using electric, hydrogen, and solar energy for hybrid vehicles. The results obtained aim to help the sector's stakeholders better understand current research in terms of the global research priorities, the technological categories, the top patenting organizations, joint patents, collaboration efforts, the types of hybrid vehicles and alternative energy sources, as well as the latest patents of leading companies. Moreover, we showed the importance of collaborative research in helping companies occupy leading positions in the market. These results could support the RD\&I strategic decision-making of stakeholders in the sector. Finally, our methodology can be applied in future research to other technologies.

\section{Recommendations and limitations}

The present study provides an initial outlook at research on hybrid vehicles and collaboration efforts through a systemic patent analysis. To gain more in-depth insights, it is necessary to focus on specific topics because the area of study is so large. In future research, it would be interesting to determine the correlations between the variables characterizing the trends and evolution of the technical advances through technology mapping. Moreover, it is important to remember that patent analysis only covers one part of the industry's strategic diversity; a more extensive market analysis is needed. Toyota, the leader in patent and collaborative activity, saw its market share erode in 2013 following an increase in sales by its competitors. Thus, the company Ford has recently significantly

\begin{tabular}{|l|c|c|}
\hline \multicolumn{3}{|c|}{ Table 6. The most recent patents granted to the top companies } \\
\begin{tabular}{|c|c|c|}
\hline in the field of solar energy \\
\hline Patent Number & Applicant & Publication Date \\
\hline JP2014176251-A & Nippondenso Co. Ltd. ( NPDE-C) & 22.09 .2014 \\
\hline JP2014174876-A & Nippondenso Co. Ltd. ( NPDE-C) & 22.09 .2014 \\
\hline JP2014171274-A & Nippondenso Co. Ltd. ( NPDE-C) & 18.09 .2014 \\
\hline JP2014166056-A & Nippondenso Co. Ltd. ( NPDE-C) & 08.09 .2014 \\
\hline JP2014166055-A & Nippondenso Co. Ltd. ( NPDE-C) & 08.09 .2014 \\
\hline
\end{tabular} \\
Source: Derwent Innovation Index Patent Database [Thomson Reuters, 2014b]. \\
\hline
\end{tabular}


increased its presence on the alternative fuel vehicle market; pure electric vehicles, such as the Tesla Model S and Nissan Leaf, have also been quite successful [MarketLine, 2014].

Nevertheless, Toyota continues to be innovative, as discussed earlier. At the start of this year, Toyota launched the latest versions of their hybrid vehicles in Japan. Expert analysts of the industry predict they will be very successful in this market.

\section{References}

Boesel J. (2013) Hybrid vehicle technology and trends. Fleet Maintenance, vol. 17, no 1, pp. 22-24.

Brody R. (2008) Issues in defining competitive intelligence: An exploration. Engineering Management Review, vol. 4, no 3, pp. 3-16.

Burns K., Levings S. (1993) How many years until mangrove ecosystems recover from catastrophic oil-spills. Marine Pollution Bulletin, vol. 26, no 5, pp. 239-248.

Calof J., Richards G., Smith J. (2015) Foresight, competitive intelligence and business analytics - Tools for making industrial programs more efficient. Foresight-Russia, vol. 9, no 1, pp. 68-81.

Custommedia (2014a) Las ventas mundiales de híbridos Toyota superan los seis millones de unidades [Worldwide sales of Toyota hybrid vehicles exceeded six millions units]. Available at: http://www.compromisorse.com/ rse/2014/01/15/las-ventas-mundiales-de-hibridos-toyota-superan-los-seis-millones-de-unidades/, accessed 15.01.2014 (in Spanish).

Custommedia (2014b) Las ventas globales del Nissan Leaf alcanzan las 100.000 unidades [Worldwide sales of Nissan Leaf achieved 100,000 units]. Available at: http://www.compromisorse.com/acciones-rse/2014/01/21/las-ventasglobales-del-nissan-leaf-alcanzan-las-100000-unidades/, accessed 21.01.2014 (in Spanish).

Denisova L., Efremenkova V., Kusch G., Ponomarenko T. (2011) Bibliometric analysis of patent documents disclosed in the information products of the RAS All-Russia Institute of S\&T Information. Scientific and Technical Information Processing, vol. 38, no 2, pp. 123-131.

Dijk M., Yarime M. (2010) The emergence of hybrid-electric cars: Innovation path creation through co-evolution of supply and demand. Technological Forecasting and Social Change, vol. 77, pp. 1371-1390.

Emadi A. (2005) Handbook of Automotive Power Electronics and Motor Drives (1st ed.), Washington, D.C.: Taylor \& Francis Group.

Forrester J.W. (1961) Industrial Dynamics (1st ed.), Cambridge, MA: MIT Press.

Global Data (2014) Toyota Motor Corporation Report no 7203: Alternative energy deals and alliances profile. Available at: http://globalcompanyintelligence.com, accessed 01.05.2014.

Karamitsios A. (2013) Open innovation in EVs: A case study of Tesla Motors (PhD Dissertation), Stockholm: KTH School of Industrial Engineering and Management.

Khan I.A. (1994) Battery chargers for electric and hybrid vehicles. Power electronics in transportation: Proceeding of the 1994 workshop on power electronics in transportation, IEEE, Michigan, USA, pp. 103-112.

Korzeniewski J. (2013) Toyota, Ford decides to end hybrid collaboration before it starts. Available at: http://www. fordinsidenews.com/forums/showthread.php?16897-Toyota-Ford-decide-to-end-hybrid-collaboration-before-it-sta rts\&s=65a36bad9fd7fc7a93bbacbc010040a5, accessed 23.07.2013.

Kraft T. (2012) Electric vehicles: A historical snapshot. Tech Directions, vol. 72, no 4, pp. 16-19.

Kwon Y., Jeong D. (2013) Analysis on patent activity and technical diversity in green car fields. Collnet Journal of Scientometrics and Information Management, vol. 7, no 1, pp. 141-159.

Lai K., Mei-Lan L., Shu-Min Ch. (2006) Research trends on patent analysis: An analysis of the research published in library's electronic databases. Journal American Academy of Business, Cambridge, vol. 8, no 2, pp. 248-253.

Lee S., Kang S., Oh M., Kim K., Park E., Lee S., Park Y. (2006) Using patent information for new product development: Keyboard-based technology roadmapping approach. Proceedings of the Conference Technology Management for the Global Future (PICMET) 2006, Istanbul, vol. 3, pp. 1496-1502.

Lugo M.J. (2008) Modelo de evaluación de tecnología basado en la conjunción de análisis de patentes y roadmapping [Technology evaluation model based on combining patent analysis and roadmapping] (MSc Dissertation), México: Tecnológico de Monterrey (in Spanish).

Marinescu M., Toti M., Tanase V., Plopeanu G., Calciu I. (2011) The effects of crude oil pollution on physical and chemical characteristics of soil. Research Journal of Agricultural Science, vol. 43, no 3, pp. 125-129.

MarketLine (2014) Hybrid and electric cars in the US: Two differing strategies. Available at: http://www. researchandmarkets.com/reports/2847651/hybrid-and-electric-cars-in-the-us-two-differing\#pos-0, accessed 08.04.2015.

Márquez R. (2007) Inquietan efectos de contaminación. Available at: http://reforma.vlex.com.mx/vid/inquietanefectos-contaminacion-195524423, accessed 05.03.2007.

Mogee M. (1991) Using patent data for technology analysis and planning. Research-Technology Management, vol. 34, no 4, pp. 43-51.

Momoh O., Omoigui M. (2009) An overview of hybrid electric vehicle technology. Paper presented at the 5Th IEEE Vehicle Power and Propulsion Conference 2009, Michigan, USA.

Moretti M. (2004) The talent war: CI in the hiring process. Available at: http://www.imakenews.com/eletra/mod_ print_view.cfm?this_id=248432\&u=scip2\&issue_id=000048936\&show=F,F,F,T,F,Article,F,F,F,F,T,T,F,F,T,T, accessed 12.04.2004.

Porter A.L., Cunningham S.W., Sanz A. (2015) Advancing the Forecasting Innovation Pathways Approach: Hybrid \& Electric Vehicles Case. International Journal of Technology Management (forthcoming). 
Ramos A. (2011) Elaboración de mapeos tecnológicos retrospectivos integrando el análisis de patentes con el technology roadmapping [Development of integrated technology maps and retrospective patent analysis in technology roadmapping] (MSc Dissertation), México: Tecnológico de Monterrey (in Spanish).

Ranaei S., Karvonen M., Suominen A., Kässi T. (2014) Forecasting emerging technologies of low emission vehicle. Proceedings of the Infrastructure and Service Integration Conference (PICMET) 2014, Kanazawa, vol. 1, pp. $2924-$ 2937.

Rodríguez M. (2003) Análisis de patentes en la inteligencia competitiva y tecnológica: el caso de los materiales avanzados [Patent Analysis in the competitive and technological intelligence: The case of advanced materials], Puzzle: Revista Hispana de la Inteligencia Competitiva, vol. 2, no 8, pp. 4-9.

Rodríguez M., Esquivel D. (2013) Advances in solar and thermal energy for hybrid vehicles: A patent trend analysis. ARPN Journal of Systems and Software, vol. 3, no 3, pp. 31-39.

Rodríguez M., Tello M. (2012) Applying patent analysis with competitive technological intelligence: The case of plastics. Journal of International Business Studies, vol. 2, no 1, pp. 51-58.

Sawin J. (2012) Renewables 2012 Global Status Report. Available at: http:// map.ren21.net/GSR/GSR2012_low.pdf, accessed 11.06.2012.

Sewe E., León N. (2010) Hybrid vehicle stirling engine and thermal energy storage (MSc Dissertation), México: Tecnológico de Monterrey.

Streltsova E. (2014) Patent activity in biotechnology. Foresight-Russia, vol. 8, no 1, pp. 52-65.

TechNavio (2014) Global Hybrid Electric Vehicle Market 2014-2018. Available at: http://www.researchandmarkets.com/ research/d7jqnk/global_hybrid, accessed 08.04.2015.

Thomson Reuters (2009) Derwent Innovation Index ${ }^{\text {sm }}$. Available at: http://images.webofknowledge.com/WOK46/help/ DII/hcodes_classes.html, accessed 08.04.2015.

Thomson Reuters (2014a) Web of Science. Available at: http://wokinfo.com/products_tools/multidisciplinary/dii/, accessed 08.04.2015.

Thomson Reuters (2014b) Derwent Innovation Index ${ }^{s m}$ Patent Database. Available at: http://thomsonreuters.com/en/ products-services/intellectual-property/patent-research-and-analysis/derwent-world-patents-index.html, accessed 31.10.2014.

Toyota Motor Corporation (2008) Annual report pursuant to section 13 or 15(d) of the securities exchange act of 1934. Available at: http://www.sec.gov/Archives/edgar/data/1094517/000119312508140299/d20f.htm, accessed 25.06.2008.

Toyota Motor Corporation (2014) Toyota launches fully redesigned 'Voxy' and 'Noah' minivans in Japan; class-first hybrid system achieve Fuel Efficiency of $23.8 \mathrm{~km} / \mathrm{L}$. Available at: http://www2.toyota.co.jp/en/news/14/01/0120.htm, accessed 20.01.2014.

Trappey C., Trappey A., Wu Ch. (2010) Clustering patents using non-exhaustive overlaps. Journal of Systems Science and Systems Engineering, vol. 19, no 2, pp. 162-181.

Trappey C., Wu H., Taghaboni-Dutta F.A. (2011) Using patent data for technology forecasting: China RFID patent analysis. Advanced Engineering Informatics, vol. 25, no 1, pp. 53-64.

Urdiales J., Limón R. (2009) Vehículos híbridos: acoplamiento sinérgico de motor térmico y eléctrico [Hybrid vehicles: Synergistic coupling of heat and electric engines]. Available at: http://www.udg.edu/LinkClick.aspx?fileticket=rwBd BYO8gjY\%3D\&tabid=8702\&language=ca-ES, accessed 05.10.2009 (in Spanish).

U.S. Department of Energy (2005) History of electric vehicles: the early years (1890-1930), Washington, D.C.: U.S. Department of Energy. Available at: http://wwwl.eere.energy.gov/vehiclesandfuels/avta/light_duty/fsev/fsev_history. html, accessed 11.06.2005.

Van Brakel P. (2005) Innovation and competitiveness in South Africa: The case for competitive intelligence as an instrument to make better use of information. South African Journal of Information Management, vol. 7, no 1, pp. $1-2$.

Ventana Systems Inc. (2006) Vensim Personal Learning Edition (PLE). Available at: http://vensim.com/vensimpersonal-learning-edition/, accessed 16.01.2015.

Visnic B. (2011) Ford and Toyota to collaborate on hybrid trucks. Available at: http://www.edmunds.com/autoobserverarchive/2011/08/ford-and-toyota-to-collaborate-on-hybrid-trucks.html, accessed 22.08.2011.

WIPO (2014a) World Intellectual Property Organization database. Section B - Performing Operations; Transporting. Available at: http://cip.oepm.es/ipcpub/\#lang=es\&menulang=ES\&refresh=page\&notion=scheme\&version=2006010 $1 \&$ symbol=B60W0010180000, accessed 28.02.2014.

WIPO (2014b) World Intellectual Property Organization database. Section B - Performing Operations; Transporting. Available at: http://web2.wipo.int/ipcpub/\#refresh=page\&notion=scheme\&version=20130101\&symbol=B60, accessed 02.10.2014.

Zemke R. (2001) Systems thinking. Journal of Training, vol. 38, no 2, pp. 40-46.

Zhou S., Wu Z., Li J., Zhang X. (2014) Real-time energy control approach for smart home: Energy management system. Electric Power Components and Systems, vol. 42, no 3-4, pp. 315-326. 